\title{
The Classical Commentary in Renaissance France: Bilingual, Mixed-Language, and Translated Editions
}

\author{
PAUL WHITE
}

University of Leeds

This article analyzes the dynamic interactions of Latin and the vernacular in commentary editions of the Latin classics printed in France before 1600, addressing questions of readership, intended uses, and actual uses. Beginning with the output of Antoine Vérard, it explores the different possibilities for translating Latin commentaries in the early decades of French printing, and the reconfigurations of layout and commentary discourse between languages. There follows a discussion of bilingual and mixed-language editions intended for use in the Latin grammar class and beyond (Mathurin Cordier, Charles Estienne, Jean Herisson, Guillaume Durand, and Pierre Davantès). Particular attention is given to evidence for the uses of such texts in the form of contemporary readers' annotations and marks of use.

Cet article analyse les interactions dynamiques entre le latin et les langues vernaculaires dans les éditions commentées des classiques latins publiées en France avant 1600. Il aborde les questions de la lecture, des intentions d'utilisation visée et des utilisations effectives. En commençant avec l'œuvre d'Antoine Vérard, on y explore les différentes possibilités de traduction de commentaires latins dans les premières décennies de l'imprimerie française, ainsi que les transformations de mise en page et de mise en regard des textes des deux langues. On poursuit en examinant les éditions bilingues et polyglottes développées à l'intention de l'enseignement du latin dans les classes de grammaire et au-delà (Mathurin Cordier, Charles Estienne, Jean Herisson, Guillaume Durand and Pierre Davantès). Une attention spéciale est accordée au témoignage que fournissent les annotations de lecteurs contemporains et les marques de leur utilisation des ouvrages.

$\mathrm{T}$ The first century of French printing saw the production of thousands of commentary editions of the Latin classics. Study of developments and variations in the production and use of these editions furnishes often unexpected evidence of the dynamic interactions between Latin and vernacular humanism in education and in literary culture. What emerges is not simply a linear story of the decline of Latin in inverse proportion to the rise of the vernaculars, as the monolingual Latin commentary editions typical of the first decades of print give way to monolingual French commentary editions by the middle and end of the sixteenth century. Rather, the use of 
mixed-language and bilingual commentary texts throughout this period in both print and manuscript speaks of a long history of interactions between Latin and the vernacular in encounters with classical texts. They provide an essential part of the context for understanding what was, in reality, a bilingual culture of teaching and learning which profoundly shaped attitudes towards language and literary composition.

Recent studies have emphasized the dynamic and richly productive interactions of Latin and the vernacular in the domain of humanist literary culture. ${ }^{1}$ Thus far, however, little attention has been given to such interactions in the realm of education and in the wider uses of classical commentary editions. Some preliminary work has been done on vernacular and bilingual commentary editions from the point of view of translation studies, ${ }^{2}$ but most of the key texts remain unstudied, particularly in respect of their intended and actual uses. In this article I aim to make a contribution to the debate on the nature of humanism, in France and elsewhere, by giving a more comprehensive picture of how such texts were used, by whom, in which settings, and to what ends. In particular, a close analysis of the dynamics of the printed pageinteractions between text and commentary, between print and manuscript, and between Latin and vernacular languages - will furnish new insights into questions of readership, the process of reading, and the different purposes for studying Latin literature. The analysis will also bring into focus a range of issues, from the shifting configurations of voice and authority in commentaries to their engagements with religious, social, and political issues and their relation to developments in education, poetics, and translation methodology.

1. For recent critical approaches focusing on the "dynamics" of neo-Latin and the vernacular, see Tom Deneire, ed., Dynamics of Neo-Latin and the Vernacular: Language and Poetics, Translation and Transfer (Leiden: Brill, 2014); and Jan Bloemendal, ed., Bilingual Europe: Latin and Vernacular CulturesExamples of Bilingualism and Multilingualism c.1300-1800 (Leiden: Brill, 2015). For notions of the "symbiosis" of Latin and the vernacular, see Philip Ford, The Judgment of Palaemon: The Contest between Neo-Latin and Vernacular Poetry in Renaissance France (Leiden: Brill, 2013).

2. Valerie Worth-Stylianou, "Translations from Latin into French in the Renaissance," in The Classical Heritage in France, ed. Gerald Sandy (Leiden: Brill, 2002), 137-64; "Reading Monolingual and Bilingual Editions of Translations in Renaissance France," in Translation and the Transmission of Culture between 1300 and 1600, ed. J. Beer and K. Lloyd-Jones (Kalamazoo MI: Kalamazoo Press, 1995), 331-58; Practising Translation in Renaissance France: The Example of Etienne Dolet (Oxford: Clarendon Press, 1988). 


\section{Translated and transmuted commentaries}

Printed vernacular commentary editions of the classics in the first decades of print give evidence of a range of different types of interactions with Latin commentary traditions. In terms of format and layout, vernacular printers adopted modes of presentation from the printed Latin editions, but also from manuscript traditions of vernacular translations, which themselves might either adopt layouts imitative of the Latin commentary texts, or, to varying extents, elide distinctions between text and gloss. ${ }^{3}$ In terms of the content of commentaries, glosses and comments were often translated or adapted from existing Latin commentaries, or from new ones, and the writers of Latin commentaries might compose them with the explicit aim that they be translated into the vernacular. ${ }^{4}$ It is not usually easy to pinpoint and name the sources for these paratexts and interpolations. Commentary is an inherently tralatitious form of writing, which is to say that commentaries almost always draw on and engage with other commentaries. In the pre-print era, it usually makes more sense to speak of commentary traditions than of original commentaries attributed to individual authors. In some cases, though, we can trace translated commentaries to their sources, and these are the first point of focus of the present article: cases of direct translation of commentary texts from Latin into the vernacular, done for various purposes and with various intended audiences.

The first important producer of French commentary editions of the classics was the Parisian bookseller Antoine Vérard. ${ }^{5}$ Vérard was active between 1485 and 1512, and his editions of the classics exemplify the different possibilities for translating commentary in late-medieval France and chart the evolving presentation and reception of such commentaries as vernacular humanism

3. On the "complex interrelation" of translation and expositio/interpretatio in the Middle Ages, see Ralph Hanna, Tony Hunt, R. G. Keightley, Alastair Minnis, and Nigel F. Palmer, "Latin Commentary Tradition and Vernacular Literature," in The Cambridge History of Literary Criticism Vol. 2: The Middle Ages (Cambridge: Cambridge University Press, 2005), 363-64.

4. For this practice see Paul White, Jodocus Badius Ascensius: Commentary, Commerce and Print in the Renaissance (Oxford: Oxford University Press, 2013), 223-24.

5. On whom, see John Macfarlane, Antoine Vérard (London: Bibliographical Society, 1900); Mary Beth Winn, Anthoine Verard, Parisian Publisher 1485-1512: Prologues, Poems, and Presentations (Geneva: Droz, 1997); and Masami Okubo, "Antoine Vérard et la transmission des textes à la fin du Moyen Age," Romania 125.3-4 (2007): 434-80. 
began to take hold. Some of Vérard's French editions of the classics followed the medieval practice of incorporating commentary into the text. Others formally distinguished text and gloss. Others imitated the form of the Latin commentary editions more closely, presenting fuller commentaries translated from Latin commentaries that had recently appeared in print.

Like many French printers in this period, keen to meet the growing demand for vernacular books, Vérard drew on the rich store of texts dating from the fourteenth and early fifteenth centuries. He published a number of translations of the classics, many of them dating from the period during and immediately after the reign of the Valois king Charles V (1364-80), whose program of cultural enrichment included the commissioning of a great number of French translations of classical texts. ${ }^{6}$ These translations included Aristotle's Ethics and Politics, by Nicolas Oresme, Valerius Maximus by Simon de Hesdin and Nicolas de Gonin, and Cicero's De senectute and Pseudo-Seneca by Laurent de Premierfait. He also published translations of histories originating in the Burgundian court context (Vasco de Lucena's Quintus Curtius), ${ }^{7}$ and products of the emerging humanist culture such as Robert Gaguin's Caesar and Livy, and early works by Claude de Seyssel, who was to undertake a translation program designed to "enrichir, magnifier et publier la langue française."

In terms of mise-en-page, Vérard favoured the alternation of text and comment, rather than the textus inclusus format that we more commonly encounter in contemporary printed Latin commentary editions. In most cases the comment follows the text, but in some (as in the Alanus and Terence) it precedes it. In this, he generally imitated the dominant presentations found in the manuscript traditions. Nicolas Oresme's (d. 1382) "commentated translations" of Aristotle, Politics (1489) and Ethics (1488), which drew substantially on the

\section{Hanna et al., 381.}

7. This translation, done for Charles the Bold by the Portuguese writer Vasco Fernandez, count of Lucena (ca. 1435-1512), is discussed by R. Bossuat, "Vasque de Lucène, traducteur de Quinte-Curce (1468)," BHR 8 (1946): 197-245. It was a translation done not with aesthetic aims in mind but to serve as moral instruction, for the education of a prince (215). To this end Vasco filled the gaps in the text with material translated from other historians. Unlike the manuscript compilations, Bossuat argues, Vasque's translation is consciously a coherent, unified narrative. Vérard's edition ca. 1500 suppresses the translator's name.

8. Rebecca Boone, “Claude de Seyssel's Translations of Ancient Historians," Journal of the History of Ideas 61.4 (2000): 561-75. 
Latin commentary traditions, formally distinguished "texte" and "glose." All but one of the extant manuscripts present the comment alternating with the text in sections, rather than in the margins, and Vérard imitated this. ${ }^{10}$ Vérard in his edition of the Hesdin/Gonesse translation of Valerius Maximus (1500) very closely follows the layout of the majority of manuscripts, including the use of the markers "texte" (or "acteur") and "translateur" (or "glose"). ${ }^{11}$ Simon de Hesdin (1375) had been careful to mark the boundaries between the text and his commentary. ${ }^{12}$

These editions of Vérard, then, correspond much more closely to the manuscript tradition for French vernacular works than to contemporary trends in the printing of Latin commentary editions. Their intended uses differed from the contemporary Latin commentary editions that presented islands of text surrounded by multiple commentaries, designed to be consulted rather than read straight through. Published by one who mainly served the particular tastes of courtly patrons for chivalric romance and history, and for devotional works, Vérard's printed books were designed to imitate sumptuous manuscripts, and many of them survive in richly illuminated presentation copies done for noble patrons. ${ }^{13}$

9. On these see Hanna et al., 382-83.

10. See Albert Douglas Menut, "Maistre Nicole Oresme: Le Livre de Yconomique D’Aristote," Transactions of the American Philosophical Society, n.s. 47.5 (1957): 783-853, 794. The exception is a presentation manuscript made for Charles V.

11. Brovarone describes the MSS: "Notes sur la traduction de Valère Maxime par Simon de Hesdin," in Pour acquerir honneur et pris: Mélanges de moyen français offerts à Giuseppe Di Stefano, ed. M. Colombo Timelli and C. Galderisi (Montreal: CERES, 2004), 183-91, 186; my own brief survey of online images from the MSS shows that all share this layout.

12. He states in his prologue that the commentary is in his own words, except where he has named his sources: "Item est assavoir que par tout ou il y a une ligne par dessoubz la lettre ce sont les paroles de valerius en propres motz ou sentence ou le propre nom daucun ou daucune chose: et ou il nen ya point soit en narracion exposicion ou declaracion ce sont mes propres paroles ou les paroles daucun autre lequel ie allegueray par nom soit philosophe: poete: ou historiographe: ou autre de quelconque estat." Nicolas de Gonin took over the translation where Hesdin abandoned it, and he is less confident in his abilities as a commentator "car ie ne suis pas si expert es histoires comme il estoit." Note however the remark of R. H. Lucas that the text is "only a paraphrase, and that at times scarcely distinguishable from the translators' commentary" ("Medieval French Translations of the Latin Classics to 1500," Speculum 45 (1970): 225-53, 225).

13. Winn, 9-10. 
Another type of "translation" of the classics in the Middle Ages was the adaptation that is more commentary than translation: what has been called the "transmuted commentary," the fourteenth-century Ovide moralisé being the most well-known example. ${ }^{14}$ In 1493, Vérard published the Bible des poètes, a synthesis in French of the French Ovide moralisé and Latin Ovidius moralizatus, done by the Bruges printer Colard Mansion in 1484. The text fits episodes from the Metamorphoses into a fourfold scheme of physical, historical, moral, and spiritual allegorizations. Vérard's edition, which was reprinted five times over the next forty years, was intended for a "wealthy and sophisticated vernacular readership." 15

Of the new or recent translations Vérard published, many drew on recently printed commentary editions of the Latin texts. Octavien de SaintGelais's Ovid and Virgil translations, published by Vérard in the first decade of the sixteenth century, incorporate into the translation text frequent moralizing and exegetical interventions. Saint-Gelais did not draw attention to his glosses or name his sources, which were, in the case of the Virgil, Servius and possibly also the newly printed commentary by Jodocus Badius Ascensius. ${ }^{16}$ Another example is Vérard's 1493 edition of the Parabolae of Alain of Lille-not a classic in our sense, but an important medieval auctor still widely used as a school textbook in the 1490s. Vérard's translator states in his prologue that the prose sections of the work are done "selon les comments," and refers often in the text to "le commentateur": in contrast with the translations of Saint-Gelais, here the fact that the annotations are translated from a Latin text is not concealed. This is because the translator, in presenting a gloss on a text for the moral instruction of schoolboys, needed to borrow the authoritative voice of an established tradition. The source is a medieval Latin commentary which had been printed in a Paris edition by Michel Le Noir around $1490 .{ }^{17}$

\section{Hanna et al., 379.}

15. Ann Moss, Poetry and Fable (Cambridge: Cambridge University Press, 1984), 6ff.

16. See Thomas Brückner, Die erste französische Aeneis: Untersuchungen zu Octovien de Saint-Gelais' Übersetzung: mit einer kritischen Edition des VI. Buches (Düsseldorf: Droste, 1987), 124-28 for examples demonstrating Saint-Gelais's use of Servius's comments in translating book 6 of the Aeneid, and 128-30 for the tentative suggestion that Saint-Gelais may have used Badius's Virgil commentary, which appeared in print two months before the manuscript presentation copy of the translation.

17. Tony Hunt, editor of the modern edition of this work-Les Paraboles Maistre Alain en françoys (Cambridge: MHRA, 2005)_identifies the paratext and commentary in this edition as translated from 
The majority of the translations of the classics published by Verardwhether old or new-were done by court writers for royal patrons. Vérard intended them to serve an aristocratic readership as well as a clientele that aspired to that condition. Others seem meant for a more general readership and show the influence of learned culture and pedagogy: they draw on Latin texts being used in Paris in the university and schoolroom environment. Many of them reproduce the sort of medieval reading practices that were still current in pre-Reformation Paris; others can be said to appeal to more of a humanist readership.

In the case of an edition of Ovid's Remedia amoris published by Vérard in 1509 , the commentary source is marked explicitly on the title page: $D u$ remède d'amours, translaté nouvellement de latin en françoys avec l'exposition des fables consonantes au texte imprimé à Paris. The text in question must be the commentary of Aegidius Delphus (Gilles van Delft, a Flemish theologian), the only commentary on the Remedia to have been printed in Paris by this date. It was first printed in Paris in 1493 by F. Balligault, and by 1506 French printers had brought out six more editions, mostly in Paris. Ann Moss describes it as a text typical of the intellectual climate of pre-Reformation Paris, "medieval in style and presentation." ${ }^{18}$

In the translation, the myths referenced by Ovid are marked in the margin by the word "fabula," and the explanations, translated into verse from the Latin prose commentary, are inserted into the text. The translation of the Latin commentary is close enough for the source to be unmistakable. The translator is on occasion able to correct the Latin commentator's errors, for example when he relocates Phyllis from Crete, where Delphus had her, to her rightful place in Thrace; ${ }^{19}$ but he also makes errors of his own, for example reading Delphus's

a medieval Latin commentary (10-11; incipit: "Iste liber duobus modis solet nominari”). That Le Noir's edition, or a common source, was the basis for the translation text in Vérard's edition is suggested by the translator's reproduction of an error ("Dum possunt tauri" for "Non possunt tauri": Parabole Alani, sig. $\mathrm{Bv}^{v}$ ), which also appears in the Latin text printed next to the translation (Le Paraboles Maistre Alain, sig. Biiii $^{v}$ ). Around the same time Vérard published the translation, Jodocus Badius Ascensius was printing in Lyon his own commentary on the Parabolae, intended to replace the medieval commentaries on the Auctores octo with one more suited to humanist study.

18. Ann Moss, Ovid in Renaissance France (London: Warburg Institute, 1982), 4.

19. Delphus describes Phyllis here as "reginam cretensem." This is not the only instance in the commentary of Delphus mixing up Thrace with Crete: he also describes the Thracian king Tereus as 
"novies" ("nine times") as "de nouveau" ("once again"). Delphus's moralizing glosses are also translated into verse and incorporated into the poem, couched in the first person singular:

\section{[...] Car cest tres chose utille}

De depposer amour caulte et subtille

Pour recorder les maulx qui viennent delle

En ostant hors son cueur de sa cordelle

Com par moymesmes vueil monstrer et prouver

Qui ay voullu tour damour esprouver (sig. i i ir $^{\text {r }}$

Delphus: Hic intendit actor probare per semetipsum quod recordatio vitiorum amicae multum valet ad amorem depondendum et quod recordando vitia puellae amatae vel alterius mulieris potest amator amorem suum deponere. Et hoc facit ut melius sibi credatur. (sig. $\mathrm{d}$ vir)

(Here the intention of the author is to demonstrate by his own example that the recollection of the faults of his girlfriend is a very effective way of getting rid of love, and that by recollecting the faults of the girl he loved or of any other woman, a lover can rid himself of love. And he does this so that he will be more readily believed. $)^{20}$

The fact that the translation of the commentary is so close, and its source is indicated on the title page, marks this as subtly different from the translation type represented by Saint-Gelais, whose verse interpolations blend into a continuous text designed to be read straight through. Here, the reader is expected to notice the departure from Ovid's source text: the translation can be used for punctual consultation and the accounts of the fables extracted for use; the book might serve as a convenient resource for preachers. The interpolations are easily noticed because of the marginal marker "fabula" and the gaps in the parallel text printed in the margins; and in the translation text itself there is a shift in voice-"comme ie puis concevoir"- the "je" here being the voice of the translator-commentator. When we return to Ovid's text, the translator marks the corresponding shift in voice: "Donc moy ovide." There is a different

"rex cretensis."

20. All English translations, except where otherwise indicated, are my own. 
mechanism at work here from that employed for the Alanus school text: here, the voice of the commentator is not that of the authoritative tradition, couched in the third person; it is a more familiar voice, a narrator's voice.

The Remedia translation was intended for a general readership without Latin, ${ }^{21}$ eager to be entertained by stories of tragic love and edified by their moral lessons. Ovid's text had described an audience of both male and female readers, and the translation emphasized the usefulness of the text's lessons for "jeunes pucelles." The translator imported material from the Latin commentary partly for the purpose of interpretation and instruction, but also to enhance the narrative. The title page notes the inclusion of material from the Latin commentary as a selling point: it is a case of added value.

Another quite different type of translation-commentary printed by Vérard is his Terence (ca. 1500). The layout supports multi-purpose uses: the full Latin text is printed in parallel columns alongside a prose translation, followed by a second translation, in verse, with a partial Latin text printed in the margins. Both translations are supplied with prose commentaries separate from the translation text.

The prose translation and its commentary, which draws on the medieval glosses, was by one Guillaume Rippe (the name given in a 1466 manuscript which contains both the translation and the notes). Jacques Monfrin remarked that Rippe's Terence represented a break from medieval translation practices: it was a new kind of translation, more identifiably humanist in conception and execution..$^{22}$ The verse translation, which is also accompanied by a commentary, is possibly by Octavien de Saint-Gelais, or by a poet called Gilles Cybille. As Ludmilla Evdokimova has shown, ${ }^{23}$ the second of these commentaries draws

21. The translator's liminary verses explain that the translation was motivated by the fact that "maintz ayment fort lescripture / Veoir et la lyre, et que plusieurs entendre / Pas bien ne peuvent, toute litterature / Ne le latin."

22. Jacques Monfrin, "Humanisme et traductions au Moyen Âge”, Journal des savants (1963): 161-90, 183.

23. "Commentaires des comédies de Térence dans l'édition de Vérard et leurs sources," Le Moyen Age 54 (2004): 95-152. See also, by the same author, "La traduction en vers des comédies de Térence dans l'édition d'Antoine Vérard : le choix du style et du destinataire," in Timelli and Galderisi, eds., 111-21. Evdokimova observes that the verse translator frequently amplifies sense and inserts concrete details; but these aspects of the translation have an expressive function and are not merely intended to make the text accessible to an uneducated readership. Likewise, the translator's tendency towards Latinization has a stylistic function and is not mere literalism. Evdokimova argues that this translation, which is aimed 
on the commentary of Donatus and on that of the Italian humanist Joannes Calphurnius (1476), but probably indirectly, via the commentaries of Guido Juvenalis and Paulus Malleolus, the former probably in the first Terence edition prepared by Badius, printed in Lyon in 1493. Juvenalis (Jouennaux) was a French schoolmaster and author of grammar texts who associated with Badius and other prominent figures of early French humanism. His commentary on Terence, of the basic schoolroom type-the kind that Badius liked to market as "familiaris" - is the most prominent source for Vérard's verse translator. As well as translating sections of Juvenalis's commentary in the notes, he has also frequently incorporated glosses from it into the text itself. ${ }^{24}$ As we have seen, this was something Saint-Gelais also did in his other translations.

Vérard's Terence was reissued in a new edition in 1539, a collaboration of several Parisian printers (Yolande Bonhomme/Thielman Kerver, Guillaume de Bossozel, Guillaume Le Bret and Jean Petit). ${ }^{25}$ The content is largely the same (with the exception of the addition of some identifying headings not in the Vérard version), but the layout and typeface presentation are different. The Latin text is set in Roman type to demarcate it clearly from the French prose, verse, and commentaries in black letter. Whereas Vérard had printed the Latin text as if it were prose, the 1539 edition gives it its proper verse presentation, making the book a more useable edition for those studying Latin. ${ }^{26}$ The title page declares that the work was designed to appeal to a readership of all classes ("vous apprendrez maintes choses subtiles et bons enseignemens pour lintroduction de tous de quelque estat quilz soient"). The readership of such texts was expanding beyond Vérard's intended audience of nobles and those who aspired to that condition.

How might such texts have been used? The 1539 edition in particular was clearly designed to appeal both to monolingual French readers and to students

at an élite readership willing to consult the original, retains certain elements of medieval translation practices but is also informed by humanist culture.

24. For example, "O Storax gentil serviteur / Ainsi nomme pour ton odeur"; Jouvenneaux: "O Storax serve sic dicte ab odore."

25. Le grant therence en francoys tant en rime que en prose nouvellement imprime a Paris (Paris: G. de Bossozel, 1539)

26. The Latin text switches to this improved presentation around the middle of the first play, suggesting an editorial intervention during the printing process. See Harold Walter Lawton, Térence en France au XVI siècle (Paris: Jouve, 1926; repr. Slatkine, 1970), 1:424. 
who needed help accessing the Latin Terence. But there is also evidence that it was used as a general language learning aid for both French and Latin. A copy held in Chetham's Library in Manchester (Mun.7.B.7.14) has been sparsely annotated by at least two sixteenth-century English readers. There are underlinings to both the Latin and the French parallel texts, though not in the corresponding places. The underlinings to the French text appear to be mostly identifying unfamiliar French words and phrases. The English marginal notes give translations of the Latin, sometimes in both English and basic French, and once or twice glosses to French expressions in English. A different hand underlines and copies out some basic French and Latin phrases and gives basic English glosses of French. The marks of use do not indicate that the English readers were using the French as an intermediary to access the Latin text; rather, they appear to be approaching both the Latin and the French texts as language-learning aids.

The type of translated commentary editions we have encountered thus far can mostly be characterized as translations of commentaries rather than commentaries on translations. The original translator's commentary incorporating comments on translation choices and methods becomes more common as the century progresses, and the practice of translating large sections of commentary from the Latin editions declines. ${ }^{27}$ Charles Fontaine's 1555 translation of the Remedia amoris provides an informative comparison with the earlier version. Like Vérard's translator, Fontaine adds some explanation, but he avoids the expansive additions typical of the earlier work. He limits exposition and interpretation to the preface and annotations, as he had done for his Heroides translation. ${ }^{28} \mathrm{He}$ adds a translator's preface, mainly taken up with an attentive discussion and justification of his translation methods. Fontaine's brief marginal notes mark points of rhetoric, ${ }^{29}$ explain ancient cultural references, ${ }^{30}$ and record textual variants. ${ }^{31}$

27. Worth-Stylianou, "Reading Monolingual and Bilingual Editions," 331-58.

28. "Et sur certains passages, i'ay fait des annotations, outre la preface: comme aussi i'ay fait le semblable sur les dix epistres du mesme Ovide, par moy traduites." Les Ruisseaux de Fontaine (Lyon: T. Payan, 1555), 347. On the Heroides translation see Paul White, “Ovid's Heroides in Early Modern French Translation: Saint-Gelais, Fontaine, Du Bellay," Translation and Literature 13.2 (2004): 165-80.

29. “Excuse du Poëte envers Cupido, avec insinuation,” 357; “Changement de propos...," 360.

30. "La lance d'Achille qui navra Telephus aussi le guerit," 361.

31. "Verba dat omnis amor, alii legunt amans," 364; "L'impression de Venise met flores: les autres mettent fructus," 365. 
Moreover, as the sixteenth century progresses, vernacular commentaries in France attach more to original compositions in the vernacular. Two years after his death, the heirs of Vérard published in 1514 a prose translation of Petrarch's Trionfi, which incorporated commentary based on the Italian of Bernardo Ilicino from the 1460s. ${ }^{32}$ One of a number of French translations of the Trionfi, the Vérard edition was a great success and was reprinted at least five times up to 1554. Following the example of Italian vernacular commentaries on Dante and Petrarch-which themselves drew on the language of the Latin commentary tradition to authorize texts written in the vernacular-French commentators start to be concerned more with style and with adding erudite support to texts written in the vernacular, Muret's commentary on Ronsard's Amours being the most prominent example. ${ }^{33}$ By this point, where annotations are published with translations of classical texts, they tend to be either more like original translators' commentaries-such as Charles Fontaine's annotations to his Remedia and Heroides translations-intended to justify translation choices and to prompt the reader to compare versions, or else pedagogical tools explicitly tailored for schoolroom use.

\section{Bilingual and mixed-language commentaries}

In shifting our attention from the type of translated commentary editions published by Vérard to the related category of bilingual and mixed-language commentary editions, we also move firmly into the orbit of the schoolroom and university. ${ }^{34}$ All of the editions to be discussed in this section, with the exception of Davantès and Durand-the latter of which is a particularly

32. Paola Ciferelli, "Jean Maynier d'Oppède et Pétrarque," in Les Poètes français de la Renaissance et Pétrarque, ed. Jean Balsamo (Geneva: Droz, 2004), 85-104, 86. Ilicino’s commentary was also separately translated into French.

33. Marc-Antoine de Muret, Commentaires au premier livre des "Amours" de Ronsard, ed. Jacques Chomarat, Marie-Madeleine Fragonard, and Gisèle Mathieu-Castellani (Geneva: Droz, 1985).

34. On bilingual textbooks used in the German-speaking lands and in England, see Nikolaus Henkel, "Printed School Texts: Types of Bilingual Presentation in Incunabula," Renaissance Studies 9.2 (1995): 212-27; Demmy Verbeke, "Cato in England: Translating Latin Sayings for Moral and Linguistic Instruction," in Renaissance Cultural Crossroads, ed. Sara K. Barker and Brenda M. Hosington (Leiden: Brill, 2013), 139-55; and Demmy Verbeke, "Types of Bilingual Presentation in the English-Latin Terence," in Bilingual Europe, ed. Jan Bloemendal (Leiden: Brill, 2015), 73-82. 
interesting case worth discussing in detail-originated in, and reflect the practices of, specific teaching situations, whether in the grammar classes of the colleges or in private lessons given in Paris and Lyon. The role of the vernacular in the teaching of Latin grammar and rhetoric was disputed ground. At the start of the sixteenth century, Erasmus, against Vives, favoured full immersion in Latin and the exclusion of the vernacular from the start; ${ }^{35}$ and Jodocus Badius Ascensius, the Parisian printer and educator whose textbooks and classical commentary editions were so widely used at this time, was reluctant to employ any vernacular language, either in the grammar classes he taught or in print: his output was almost entirely Latin. As the sixteenth century progressed, the successful bilingual textbooks of Mathurin Cordier and others bear witness to a shift in teaching practices as the vernacular became legitimized as a tool for learning Latin grammar, and ultimately, a subject worthy of study in its own right.

On the one hand, the Parisian colleges were particularly insistent that the vernacular should be excluded from the grammar/rhetoric education, and there are numerous examples of the colleges' statutes banning all but the use of Latin. ${ }^{36}$ Even Cordier, responsible for the massive proliferation of bilingual textbooks for Latin learners, emphasized the taboo attaching to French students speaking French in the schoolroom. He wrote that boys ought to be ashamed to speak French even to their mothers; in his view, the ideal schoolboy "never swears, never lies, never speaks French" ("Nunquam iurat: mentitur nunquam: vernacule nunquam loquitur"). ${ }^{37} \mathrm{He}$ complained that whereas foreign students were arriving at university already able to speak Latin fluently, having learned at school to converse exclusively in that language, French schoolboys were more likely to fall back on their mother tongue. ${ }^{38}$ Cordier privileged the ideal teaching situation of oral exchanges in the schoolroom being exclusively Latin. Nevertheless, it is clear that vernacular languages did play a part in grammar

35. Constant Matheeussen, "Le Rôle des langues vernaculaires dans l'enseignement du latin selon Georges d'Halluin, et les points de vue d'Erasme et de Vives," in Acta Conventus Neo-Latini Turonensis, ed. J.-C. Margolin (Paris: Vrin, 1980), 471-80.

36. Gabriel Codina Mir, Aux sources de la pédagogie des Jésuites: le Modus Parisiensis (Institutum Historicum S.J., 1968); Ann M. Blair, “Lectures on Ovid's Metamorphoses: The Class Notes of a 16thCentury Paris Schoolboy," Princeton University Library Chronicle 50 (1989): 117-44, 131.

37. Mathurin Cordier, De corrupti sermonis emendatione libellus (Lyon: Gryphius, 1532), 393.

38. Cordier, preface. 
school teaching in the French Renaissance, and had done since the high Middle Ages-as it had done, indeed, in Italian schools since at least the beginning of the fourteenth century. ${ }^{39}$ Translation was employed as a pedagogical exercise: there were the "themata," exercises in Latin composition based on a text given in the vernacular ${ }^{40}$ more generally, the typical paraphrastic method of reading texts in the grammar class involved both intralingual and interlingual glossing. ${ }^{41}$ But these were, on the whole, exercises done orally: translation (as opposed to Latin "thematic" composition) was not generally a written exercise until much later. ${ }^{42}$ If the vernacular was employed in the schoolroom, it was emphatically only as a means to access mastery of Latin. This is clearly the case for the numerous bilingual adaptations of the major grammar books-Donatus, Perotti, Dati, Despauterius-printed from the incunable period onwards, with Italian, French, Dutch, German, Spanish, or English text accompanying the Latin. In France, by the late sixteenth century, bilingual versions of Latin grammar books were seen as being "pour l'exercice des deux langues," and not just for learning Latin. In the seventeenth century we see books specifically designed to enable learners to use Latin as an intermediary language between their own vernacular and a foreign vernacular. ${ }^{43}$

39. The use of vernacular languages as a means of teaching Latin grammar was attested in ca. 1200 by Alexandre de Villedieu (Henkel, 213). For the Italian context, see Robert Black, Humanism and Education in Medieval and Renaissance Italy (Cambridge: Cambridge University Press, 2001), 109, 113; and "Teaching Techniques: The Evidence of Manuscript Schoolbooks Produced in Tuscany," in The Classics in the Medieval and Renaissance Classroom, ed. Juanita Feros Ruys, John O. Ward, and Melanie Heyworth (Turnhout: Brepols Publishers, 2013), 245-65; and Brian Richardson, "Latin and Italian in Contact in Some Renaissance Grammars," in Rethinking Languages in Contact: The Case of Italian, ed. A. L. Lepschy and A. Tosi (London: Legenda, 2006).

40. On the themata, see Mir, 124. See also Glyn Norton's description of the pedagogical function of translation at the Collège de Guyenne: The Ideology and Language of Translation in Renaissance France and Their Humanist Antecedents (Geneva: Droz, 1984), 140-42.

41. For the broad range of linguistic operations bound up in the term interpretatio see Paul White, "From Commentary to Translation: Figurative Representations of the Text in the French Renaissance," in The Culture of Translation in Early Modern England and France, 1500-1660, ed. Tania Demetriou and Rowan Tomlinson (London: Palgrave Macmillan, 2015), 71-85.

42. Bernard Colombat, La grammaire latine en France à la Renaissance et à l'Âge classique: théories et pédagogie (Grenoble: ELLUG, Université Stendhal, 1999), 98.

43. Colombat, 65. 
Within this context, bilingual classical editions developed partly in response to changing educational practices and partly in line with the constraints of print production and the demands of local, national, and international markets. Although the dominant type of edition being produced in the first phase of French classical printing (roughly to the end of the first third of the sixteenth century) was the monolingual Latin commentary edition, glosses in vernacular languages were not completely absent from such editions. Even Jodocus Badius Ascensius, who as we have seen favoured monolingual immersive Latin education, in his Latin commentaries occasionally had recourse to vernacular glosses, in Parisian French, in Franco-Provençal (since he had begun his teaching career in Lyon), and in Flemish. One might relate the general absence of such glosses in these editions to contemporary pedagogical practices-taking them as evidence for the exclusion of the vernacular in the teaching of these texts-but an equally important factor is the market. Monolingual Latin editions were more mobile and marketable to students in different language communities, whereas editions with glosses in specific vernaculars would have been limited to local markets: we can assume that teachers using these monolingual texts were expected to orally supply-if necessary-vernacular explanation in the local dialect.

An illustration of the challenges faced by printers who wanted to adapt for local readerships bilingual Latin textbooks produced for other language communities is the Latin grammar of Aldus Manutius (Institutiones grammaticae). ${ }^{44}$ In his sections on the use of participles, Aldus had included some examples in Italian as a contrast to illustrate the specific requirements of Latin grammar. When French printers (Badius, Poncet Le Preux, Robert Estienne, and others) produced versions of the grammar in Paris and Lyon from 1513, the Italian was replaced by French, but no effort was made to adjust the text to the different requirements of French grammar. Since French does not use participles in the same way as Italian, all of the examples given by Aldus to distinguish between constructions where Latin cannot use a participle and the vernacular can now make little sense: the French examples do not use a participle, either, but must use a relative pronoun and indicative verb as does

44. On the uses of the Italian vernacular (Tuscan and non-Tuscan forms) in this text see the forthcoming article by Brian Richardson, to whom I am grateful for sharing a pre-publication version: "Aldo Manuzio and the Uses of Translation," in Collectanea Manutiana: studi critici su Aldo Manuzio, ed. Pier Davide Accendere and Stefano U. Baldassarri (Florence: Le Lettere). 
the Latin. In Le Preux's edition, the grammar of the first example given by Aldus is completely mistranslated-the Estienne edition corrects the error.

Printed books designed for educational uses do not by themselves tell the whole story of classroom practices. Manuscript notes taken down by students in real teaching situations help flesh out the picture. A number of printers, including Thomas Brumen, Denis Du Pré, Gabriel Buon, André Wechel, Thomas Richard, and Matthieu David, produced editions of classical texts specifically designed to be annotated by students following courses taught at the collèges of the University of Paris. These books all adopt a similar presentation designed to facilitate note-taking in classes-wide margins and double-spaced text-and the surviving copies often contain interleaved pages of manuscript commentary. I have seen numerous copies dating from the 1540 s to the 1580s, and the student annotations they record are remarkably consistent in form. In the majority of cases, they are monolingual: all interlinear glosses and marginal commentary are in Latin. However, there is some evidence for bilingual approaches in the Latin grammar and rhetoric classes in the Paris colleges. A British Library copy of Brumen's 1569 edition of book 15 of Ovid's Metamorphoses (826f5[5]) bears the course notes of an anonymous student, with the dictated commentary in Latin in the margins and interleaved pages, and an interlinear translation in French. That the French translation was part of the teaching, rather than being the student's own initiative, is proved by the fact that there are occasional gaps, each of about ten lines, in the interlinear glosses, which indicates that the student missed an hour of teaching here and there. The Christie collection of the John Rylands Library in Manchester holds two course texts of a similar type (48a9 and 48f19), both of which contain notes taken down from the dictation of one Jean de Rouen in the Collège de Bourgogne in Paris. ${ }^{45}$ The notes record a course on selections from the Epodes taught in 1571, and a course on the first book of the Odes in 1573. The magister's dictated commentary is in many places lifted verbatim, and completely without attribution, from the printed commentary on Horace of Denis Lambin. The classes are quite advanced, and clearly belong to one of the top classes of the Arts course, i.e., the point of transition from the basic "grammar" classes to the

45. Q. Horatii Flacci venusini poetae lyrici poemata [Odes book 1] (Paris: T. Brumen, 1568); and Ex Q. Horatii Flacci Epodon libro Odae quinque selectae cum argumentis et brevibus quibusdam annotationibus (Paris: Denis du Pré, 1570). Title page inscriptions by an anonymous student owner record the place and dates of the courses, and the name of the professor. 
"rhetoric" class: in other words, the students were expected to have advanced beyond the point where vernacular explanations would be needed. Unlike the Ovid course, both the commentary and the interlinear glosses are in Latin, some clearly "first order" notes taken down at dictation speed, others (the interleaved pages) perhaps "second order" notes written out more neatly. However, towards the end of the course (the penultimate poem of book 1 of the Odes) the student annotator's attention starts to flag and he lapses into his mother tongue in two short glosses: "[un] triumphe d'Auguste"; [the Liburnian galleys] "dont se servit Auguste contre Antoine." Either the magister, Jean de Rouen, was also using French in his oral explanations (but students were not supposed to write this down), or else the student, unable to keep up with the Latin dictation, has briefly lapsed into the illicit vernacular.

How did these practices, evidenced by manuscript annotation, relate to the production of printed texts? In the second third of the sixteenth century, French printers produced a number of classical editions in a bilingual LatinFrench presentation, often accompanied by commentaries. The authors and texts represented by these editions were those most prominently taught in the grammar and rhetoric classes, namely the Disticha Catonis, the comedies of Terence, and the letters of Cicero.

Cordier, the hugely influential educator whose bilingual Latin textbook Colloquia would enjoy a widespread popularity lasting hundreds of years, designed a number of such texts based on his teaching at the Collège de Nevers and elsewhere. His first experiments with the format were with the mainstay of elementary Latin education, the Disticha Catonis, but the same format (text in Latin followed by commentary breaking down the Latin phrase by phrase, with interjected French translation) was later adopted for bilingual editions of Cicero's letters, a text Cordier thought more suitable than Cato for early grammar instruction. The Cicero editions based on his teaching mark a new phase in the production and use of bilingual commentary editions of the classics. As well as reflecting contemporary pedagogical practice, such editions parallel the development of a "comparative" approach to language as exemplified by Robert Estienne's Dictionnaire, as Valerie Worth-Stylianou has shown. ${ }^{46}$ 
Cordier, indeed, had collaborated with Robert Estienne for his first Cato edition in 1533, an edition so successful that it was reprinted and adapted countless times in the next decades (including editions with English and German replacing the French). ${ }^{47}$ In 1542, the printer Louis Grandin, a former pupil of Cordier's at the Collège de Navarre, undertook to produce a Cicero edition-a selection of letters from book 2 of the Epistulae ad familiares-compiling the bilingual commentary from the notes he had taken down in Cordier's lessons (Preface in 1549). Cicero's letters were widely taught in the colleges as models for epistolary composition, which was, according to Grandin, precisely the aim of Cordier's lessons. The commentary itself consists of little more than a phrase-by-phrase Latin paraphrase with interjected French translations. It was slightly expanded in Grandin's 1544 edition, which added more letters from book 2 supplemented with translation/commentary by Robert Britannus, whose teaching method replicated that of Cordier. Here is an extract from the 1544 edition, showing how the text switches freely between Latin and French for the gloss and paraphrase:

Quamobrem || Et pource.

Si tu potes existimare) iudicare.

Me memorem) sub. beneficiorum acceptorum || si tu me veuls iuger estre memoratif des biensfaictz.

Si gratum || homme recognoissant le plaisir. Memor, in habenda gratia: Gratus, in referenda. Memor beneficii || celuy auquel il souvient du plaisir qu'on luy a faict: c'est a dire, qui en scait tousiours bon gre. Gratus \| ung homme recognoissant: c'est a dire, celuy qui rend voluntiers le plaisir en temps et lieu. Contra, Immemor et Ingratus, qui de beneficio accepto nec habet gratiam, nec eam refert. ${ }^{48}$

Quamobrem || Therefore.

Si tu potes existimare) judge.

Me memorem) understand: of benefits received || if you will judge me to be mindful of benefits.

47. Du Verdier estimated over one hundred editions; see Jules Le Coultre, Mathurin Cordier et les origines de la pédagogie protestante dans les pays de langue française (1530-1564) (Neuchâtel, 1926), 73-90. For the English adaptation, see Verbeke, “Cato in England," 146-47.

48. Cicero, Epistolarum familiarum liber secundum cum latina et gallica interpretatione (Paris: L. Grandin, 1544), 37. 


\begin{abstract}
Si gratum || a man showing gratitude. "Memor," being thankful: "Gratus," repaying thanks. Memor beneficii || one who remembers the good turns done to him by others: that is, one who is always grateful for them. Gratus II a man who shows gratitude, that is, who freely repays the good deed at the right time and place. The opposite: "Immemor" and "Ingratus," one who is neither thankful for benefits received, nor repays thanks.
\end{abstract}

Grandin printed a 1549 edition with more letters (from the Ad Atticum and by Seneca) and issued a further expansion in 1558, though this time without the full text of the letters themselves. Thus, Cordier's pedagogical method of bilingual paraphrase translated successfully into print and was used as a template for new contributors as successive editions incorporated more and more material. ${ }^{49}$

The format adopted by Grandin spawned imitators outside of France. Christophe Plantin produced a trilingual Latin-French-Dutch edition of Cicero's letters in $1577 .^{50}$ As with Grandin's editions, the Latin text was accompanied by an "ordo et expositio," a phrase-by-phrase breakdown and translation, distinguishing language by typeface (roman for Latin, italic for French, black letter for Dutch); but Plantin adopted a slightly different mise-enpage, setting the explanation underneath the text on every page, and adding at the base of each page a word-list divided into parts of speech.

Other bilingual learners' editions of the grammar class texts elaborated on the basic text and bilingual paraphrastic commentary format. Charles Estienne's 1541 edition of Terence's Andria presented the text in Latin followed by two explanatory sections combining Latin and French: the "Constructio," giving the phrase-by-phrase breakdown and translation of the text, was followed by a section entitled "Scholia" commenting more fully in Latin, again with interjected French translations. ${ }^{51}$ Again, this is an edition adapted to the

49. On Grandin's editions see also Le Coultre, 282-91; Le Coultre, however, is unaware of the 1544 edition and the contributions of Britannus.

50. Cicero, Aliquot Faciliores Epistolae, in Periodos Quasi Lectiones Singulas Partitae Cum Interpretatione Gallica \& Flandrica (Antwerp: Plantin, 1577).

51. See Lawton, 1:427-39. Lawton comments at length on the bilingual editions of Terence, but has little to say about their commentaries, formats, and intended uses, being more interested in evaluating the literary quality and correctness of the translations. See also Bénédicte Boudou and J. Kecskeméti, Robert et Charles Estienne, des imprimeurs pédagogues (Turnhout: Brepols, 2009), 347. 
actual practice of school reading. Like Cordier, Estienne based the text on his own teaching, mentioning in his preface the origin of the book in lessons given to "adolescentulis meis." Estienne clearly saw himself as picking up on and improving the format innovated by Cordier: he also produced a rival Cato edition in response to Cordier's, replacing the latter's bilingual commentary with one of his own $(1538,1541,1547,1560)$, and pointedly stating in the preface that his commentary was totally different from Cordier's, since it integratedand properly attributed-the comments of Erasmus. He later printed an edition of Cordier's bilingual Cicero (1555), promising to add further instalments in the series.

The Estienne Terence was very successful: Harold Walter Lawton lists further editions in Paris by Robert and by François Estienne (1546, 1547, 1548); by Thibault Payen in Lyon in 1547 and 1561; and by Birckmann of Leuven in 1549 , with a Spanish translation replacing the French. ${ }^{52}$ Other editions not mentioned by Lawton include Lyon: Jean de Tournes, 1548 and 1556; Lyon: Guillaume Rouillé, 1547.

The following extract gives a sense of the approach taken by Estienne in the "Constructio" section:

Nihil opus est) Non est mihi necessarium, Non opus habeo, Ie n'ay ia de besoing

Istac arte) hac sedulitate et diligentia, quam praedicas, de ceste diligence $a$ quoy tu t'es offert par ci devant. Arte pro artibus, figurate positum.

Ad hanc rem quam paro) ad hoc negotium quod nunc molior, a c'est [sic] affaire que i'entreprens,

Sed his) [artibus] mais plutost de celles. zeugma est a superiore: cum subaudiatur, artibus: prius autem artem dixerit. ${ }^{53}$

Nihil opus est) It is not necessary for me, I have no need, I do not need Istac arte) of that assiduity and diligence that you display, this diligence to which you gave yourself over in the past. "Arte" is here used figuratively, singular for plural.

52. Lawton, 1:427.

53. Andria P. Terentii omni interpretationis genere, in adulescentulorum gratiam facilior effecta (Paris: R. Estienne, 1546), 28. 
Ad hanc rem quam paro) for this "negotium" I am now engaged in for this business I am undertaking

Sed his) [artibus] but rather of those. This is a zeugma linked to the previous expression, since "artibus" is understood: he said "artem" already.

The section entitled "Scholia" is less of a commentary on the text and more of a reference guide to Latin usage. Estienne takes expressions from the text as headings under which to accumulate parallels (predominantly from Cicero) to illustrate usage, given in both Latin and French. The similarities to the lexicographical enterprise of the Dictionarium latinogallicum, on which Charles worked with his brother Robert, are evident. The comments address schoolboys using the text as a basis to achieve oral and written facility in Latin:

Idne verum est? Est il vray? elegans loquendi formula, cum alicui comminamur ob delictum quod in eo animadvertimus. Veluti si tu condiscipulum videris aliquid minus recte agentem, hoc dicere poteris, Ah, idne est verum? vel estne id verum? profecto ego referam praeceptori. Ah, cela est il vray? ie le diray au regent. ornatius, quam si dicas, Haha, nunquid ego bene video? aut, Ego bene vidi te, tace, utrum verum est? \& similes ineptiae. $^{54}$

Idne verum est? Is that so? An elegant turn of phrase, when we are threatening someone for a transgression we have seen them commit. For instance, if you see your classmate doing something rather naughty, you will be able to say this: "Ah, idne est verum? or estne id verum? I will be sure to tell the teacher." Ah, is that so? I will tell the teacher. This is more elegant than if you were to say "Haha, nunquid ego bene video?" or "Ego bene vidi te, tace, utrum verum est?" and similar absurdities.

The format adopted by Charles Estienne for his 1541 Andria appears to have been the model for two further Terence editions produced in the 1550s by one Joannes Ericius (identified in the French-language privilege as Jean Herisson), ${ }^{55}$

54. Andria, 328.

55. The privilege was granted to Thibauld Payen to print "L'Eunuche et autres Comedies de Terence mises en latin et en francois avec additions et scholies tant Grecques que Latines par maistre Iean 
a teacher in Lyon. Thibaud Payen, the Lyon publisher of the Herisson editions, also produced reprints of the Estienne Andria in 1547 and 1561. The 1547 edition must have sold well enough in the Lyon market for him to encourage Herisson in his enterprise. Herisson's Eunuchus, first printed in 1552 and reprinted at least three times over the next decade, was followed by a posthumous edition of the Heautontimoroumenos (1559) - also Payen's initiative-but the projected full series of Terence comedies in this format never materialized. Herisson's preface to the Eunuchus relates that he had been teaching the text in private lessons, and these are the notes he had been dictating to his pupils, which Estienne Pasquier had encouraged him to publish in print.

Herisson's Terence editions thus derive directly from his grammar teaching in Lyon. The front matter consists of a series of explanations and arguments typical of the monolingual commentary editions, but Herisson supplies French translations in italic typeface of the Latin paratexts in roman. The Latin text of the plays is then supplemented scene by scene with a section headed "SYNTAXIS," under which the Latin is broken down and occasional brief Latin glosses are added, with interjected French translations of the Latin and its gloss:

PAR. Ah indignantis interiectio

Rogitare [mirum est, supple, te rogitare.] Cest merveille de ce que tu me presses si fort. aut pergis supple rogitare? Perseveres tu encore de m'en presser? Interrogative.

Quasi difficile sit [complere supple quod iubes.] Comme sil estoit bien

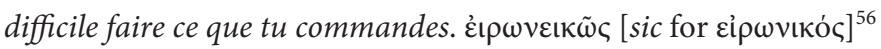

\section{PAR. Ah: interjection of one who is exasperated.}

Rogitare [supply: "it is amazing that you are asking the question"] It is amazing that you are being so insistent with me. Alternatively, supply: "are you persisting in asking?" Are you still insisting on the point? Interrogative.

Herisson.” Pub. Terentii Eunuchus, Latinè \& Gallicè in studiosorum adolescentum gratiam enarrata (Lyon: Jean Temporal, 1554).

56. Terence, Eunuchus (Lyon, Jean Temporal, 1552), 62. 
Quasi difficile sit [supply: "to fulfil your command"] As if it were really difficult to do what you are ordering. Sarcastic.

Where the meaning of the Latin is in doubt, Herisson gives both interpretations..$^{57}$ Following the Estienne model, Herisson supplies fuller grammatical commentary in a section headed "SCHOLIA":

Missum facere, $\pi \varepsilon \rho \iota \varphi \rho \alpha \sigma i \kappa \tilde{\omega} \varsigma[s i c]$ dicitur, pro omittere, et ut effectum dicit, pro efficere. Cicero pro Roscio Amerino, Verum ut haec missa faciam, quae iam facta sunt: ex iis quae nunc maxime fiunt, nonne quivis potest intelligere omnium architectum et machinatorem esse Chrysogonum? Mais prenes le cas que ie laisse, ou que ie ne die mot. Terentius Missa facio. effundite, emite, facite quod vobis lubet. Ie vous laisse faire, il ne m'en chault, despendez, achetez, faictes ce que vouldrez. Et infra: Quin effectum dabo, id est efficiam. Linacer tamen quiddam perfectius et absolutius per participia significari putat. ${ }^{58}$

Missum facere, is a periphrastic expression for "leave out," like saying "done" for "do." Cicero, Pro Roscio Amerino: "But to say no more about those things that have already been done, cannot anyone understand, from the things that are happening right now, that Chrysogonus is the architect and contriver of all this?" Take it that I am dropping the matter, or saying not a word. Terence: "I leave it to you. Squander, buy, do what you please." I leave it to you, I do not care, spend, buy, do what you wish. And later: "I'll see it done," that is, I will do it. Linacre, however, thinks that such participles express something more perfective and more absolute.

But the approach here differs from Estienne's, and these sections can more properly be called commentaries on the text. The intended readership is clearly more advanced linguistically: numerous Greek quotations are supplied (usually with Latin translation), and there are frequent references to recent grammatical

57. "Bene vertendo eas [valde transferendo in linguam Latinam, aut valde corrumpendo] En les traduisant en Latin le mieux, \& le plus diligemment quil pouvoit: ou en les traduisant bien, \& declairant mal: en les gastant \& corrompant fort. Nam utroque modo exponit Donatus." Eunuchus, 4.

58. Eunuchus, 49. 
scholarship (Linacre, Bembo, Erasmus, Ramus), along with moral-ethical commentary directed at young readers. Interjected French translations do feature in these sections, but they are relatively infrequent after the prologue.

Interestingly, this Eunuchus edition includes in appendix the rhetorical commentary of Jodocus Willichius (1501-52), a Latin commentary which itself incorporates occasional vernacular glossing (in German)-a further demonstration that these bilingual editions are not radical innovations but enlarge on a practice that is already a minor feature of many Latin humanist commentary editions.

The survival rate of bilingual classical editions-as is generally true of all early printed books frequently used in the schoolroom-is probably in inverse proportion to their popularity at the time. Another school edition of Terence in this by now familiar bilingual format survives in a single copy: $P$. Terentii Andria Latinogallica (Paris: L. Grandin, 1558), described by Lawton. ${ }^{59}$ The printer, Grandin, had also produced Cordier's Cicero editions, but varied the presentation of this Terence edition by not reproducing the Latin text in full. It is highly likely that Grandin, the Estiennes, Thibauld Payen, and other printers specializing in bilingual formats produced many more of this type of edition than survive.

In the face of the ever-growing production of Latin commentaries on Terence, attempts by French editors to innovate bilingual presentations of text and commentary culminate in the 1560 edition of Pierre Antesignanus (Davantès), the third volume of which combines Latin text and notes with French translations. ${ }^{60}$ Davantès aims at comprehensiveness, and the relatively streamlined page presentation of the earlier bilingual editions is here replaced by a crowded page, the upper half giving the Latin text surrounded by Latin comments extracted from no fewer than eighteen source commentaries, and the lower half giving the French translation set in columns alongside a French paraphrastic commentary, which also incorporates comments in Latin. Typeface and size distinguish the different components and languages.

59. Lawton, 1:483-88.

60. Terentivs, in quem triplex edita est P. Antesignani Rapistagnensis commentatio [...] Tertivm exemplar ex omnium interpretum commentariis compe[n]diosam expositionem, omne[m]que primi exemplaris argume[n]tum, Gallicam proterea translationem ad verbum in tres priores comodias ... tum etiam huius authoris peculiares annotationes, plenioresque interpretationes continet (Lyon: M. Bonhome, 1560). Citations in the main text will refer to this edition. 
The fact that Davantès provides the French only for the first three plays is probably not a coincidence: he seems to have based his French versions on the editions of Estienne and Herisson, ${ }^{61}$ although he nowhere acknowledges their existence, while being very scrupulous about the attribution of comments in Latin. Such double standards of attribution were characteristic of the difference between Latin and vernacular commentary, as was highlighted by Marco Antonio Bonciario, writing in 1604, who complained that the Latin commentaries of Jodocus Badius Ascensius on Virgil, Horace, and Cicero (which he despised) were a century later still being translated into the vernacular by unscrupulous teachers for their own use, "only suppressing the name of the author." ${ }^{62}$

Davantès's edition marks a difference in approach from the earlier bilingual editions: he treats the French not just as a means for students to access the Latin; he is attentive to translation issues. While emphasizing that the main French translation is a word-for-word version intended to enable easy comprehension of the Latin, Davantès also draws attention to the fuller and freer French translations contained in the commentary, in which he has attempted to convey the literary qualities of the text in accordance with recent ideas in translation theory, notably those of Dolet (sig. ${ }^{* *} \mathrm{ii}^{\mathrm{v} 63}$ ). Davantès's Terence edition thus spans from the bilingual editions where the French is merely a crib for and explanation of the Latin text to bilingual editions that privilege the French and scruple about the literary qualities of French. Guillaume Durand's Persius moves further in this direction

\section{Bilingual editions and literary culture}

Whereas the Terence and Cicero editions discussed thus far are all more or less clearly linked to the teaching of those authors in the grammar class, the next example is a more unusual case. Although Persius (alongside Juvenal and the hexametric Horace) had long been a relatively popular educational text, particularly for the perceived congruence of the Stoic philosophy with

61. For comparison: Estienne's French at Andria 1.1: "Vous aultres serviteurs / portez ces choses leans / retirez vous / Vienca Sosia / Ie te veuil dire ung mot / pensez desia l'avoir dit / c'estascavoir / que ce qu'avez commande, soit bien faict"; and Antesignanus: "Portez-vous-autres cecy leans: allez vienca Sosia / ie te veux (dire) un mot. Pensez (que cela est desia) dit: a savoir que cecy soit bien fait."

62. White, Jodocus Badius Ascensius, 225-26.

63. See also Lawton, 1:501. 
Christian moral education, his difficult Latin made him an unsuitable candidate for bilingual school texts in the manner of Terence and Cicero. Nonetheless, a bilingual edition of Persius was printed in 1575 by Denis du Pré, libraire juré of the University of Paris and printer of numerous course editions for the Paris colleges of the type discussed above. ${ }^{64}$ The translator-commentator was Guillaume Durand, Conseiller du roi in the présidial (regional court) of Senlis, whose other publication of this type, a bilingual version of Sulpizio's book on table manners, was very clearly designed for schoolboys. But Durand's Persius has different aims, and a different intended readership.

This is a facing-page translation edition-with the Latin accompanied by commentary and marginal notes on the verso, and the French translation with its commentary and notes on the recto-each poem preceded by a French "argument" and followed by a Latin "epilogus." The two languages are, however, not held apart by the page boundary, each encroaching at points on the space of the other language: the Latin commentary may overflow onto the recto, or on the verso switch into French ${ }^{65}$ (the two languages generally being distinguished by typeface). And unlike previous editions of this type, here the Latin and French are not strictly parallel, but have different content; this is both a bilingual and a mixed-language edition. ${ }^{66}$

Unlike the previous examples of bilingual editions, this one promotes an awareness of the fact that Persius in French is not the same Persius as Persius in Latin; the presentation, framing, and focus are different. Durand aims to make a "new French" Persius from an "old Latin" one ("ut ex vetere Latina, novam Gallicam fecisse videar," 4v). The French language sections are used for purposes different from the Latin sections, as the translator-commentator

64. Aulus Persius Flaccus brevissimis annotationibus illustratus. Le mesme Perse est en l'une des pages traduict en vers francois, par forme de paraphrase. Par Guillaume Durand (Paris: D. Du Pré, 1575). All in-text citations refer to this edition. There was at least one more edition, in 1586, also by Denis Du Pré; and there must have been an earlier edition too, since the dedication is dated 1567. This is confirmed by the subtitle of the 1586 edition, which notes that Durand had revised and augmented the text "for the second time" before his death.

65. For example, "Puteal enim locus erat Romae, ad quem conveniebant foeneratores, ut suos debitores vexarent: Alii dicunt praetoris tribunal subselliumque esse: quicquid sit, est locus in quo vexantur obaerati, Comme à Envers la bourse, à Lyon le change, à Venise Realte, à Paris la Iustice des iuges Marchantz de nouvel erigee" (56v).

66. For the distinction, see J. N. Adams, Bilingualism and the Latin Language (New York: Cambridge University Press, 2003), 30. 
expatiates on his own concerns (law, religion, politics, vernacular poetry), and attempts to familiarize the text for his French audience.

The numerous prefatory paratexts in Latin and French frame the text differently for the different language communities, the Latin focusing on the ethical function of satire and the French being concerned with literary and stylistic matters. The French arguments and commentaries also focus more on religious issues, making extensive reference to Bible authorities, largely absent from the Latin "epilogi," and developing the traditional alignment of Ecclesiastes with Roman satire. At Satire 2.70, Durand in French worries that many people (he means Calvinists) could use the passage for their own nefarious purposes, especially these days when the ceremonies of the Roman Catholic church are being attacked on all sides, but he argues against the reading. Elsewhere he prefers to avoid theological debate, skirting the question of freedom of will in the French prologue to the fifth satire. It is clear that the French sections of this bilingual commentary are heavily inflected by the pressing concerns of the ongoing religious conflict. Social issues are also a preoccupation of the French text: Durand's presentation of the first satire expresses anxieties about the social mobility of the bourgeoisie, contrasting the effects of learning on "those of noble descent" with "those that we might call 'sons of the earth,' the dregs of society" ("en ceulx que lon pourroit dire estre filz de la terre, et qui sont de la derniere presse d'un marc," $15^{\mathrm{v}}$ ). He punningly condemns the jumped-up bourgeoisie who "heedlessly sully the excellence of the liberal arts to such an extent that beneath the insubstantial cover of their haughtiness, their scarlet clothing, their amethysts and diamonds, their taffeta puffed up with the wind of pride, they become so sordid that they put a price on art [l'art] as a charcutier does his bacon [lard]." ${ }^{67}$ The anxieties about social climbers are especially pointed given Durand's own position: the présidiaux were created in 1552 by Henri II as a way of selling offices to the monied bourgeoisie.

Durand makes efforts to fit his French Persius into contemporary vernacular literary culture, in line with his own literary ambitions. In his French preface he mentions the vernacular equivalents of Roman verse satire, the "coq à l'âne," and popular entertainments such as the farce and sottie. But the French verse satire was out of favour, disdained by Du Bellay and the Pléiade

67. "Et voluntiers telles gens souillent en telle sorte l'excellence des ars liberaux que soubz l'ombre de leurs morgues, leurs escarlattes, leurs amethistes et diamantz, leurs taffetas remplis du vent d'orgeuil, se rendent si sordides qu'ilz mettent pris à l'art comme un charcuitier à son lard" (16r). 
for its association with the tainted medieval heritage and Marot. Durand therefore takes a different tack in order to fit Persius into a narrative aligned with the concerns of the Pléiade: perversely, he foregrounds ideas about poetic inspiration, asserting in the "préambule" that satirists should be considered on a par with inspired poets. The reading is a perverse one since Persius in his prologue and in Satire 5 explicitly distances satire from anything like inspired poetry; and Horace in the Sermones had said that satires were not true poetry, and certainly not inspired. Durand's interpretation thus goes against the grain of the text in order to align his French Persius with contemporary trends in vernacular poetry.

There is, however, ambivalence in Durand's account. The Wars of Religion had drawn poetry into the domain of polemic; Ronsard was the emblematic figure. In this context, Durand is concerned to provide justifications for the vision of poetry he presents. In his liminary poem "to French poets" (significant in itself; Durand was explicitly framing his translation as poetry), he rhetorically apologizes ( $2 \mathrm{r}-\mathrm{v})$ for his "vers sans mariage," for writing poetry "en coelibat," not "married to" a "debat"; the metaphor functions doubly, both to forestall a critique of the translation's disjointed style and to justify writing poetry not engaged with the political situation. His ambitions to write "inspired" love lyric are frustrated by the demand to engage with the conflict. This is partly a conventional recusatio, and partly a recasting of Du Bellay's figuration in his Latin poetry of the French language as a wife and Latin as a mistress. That Durand had aspirations as a lyric poet is clear from the liminary poem by his son Gobert in Latin Sapphic stanzas, praising Durand's achievement as a poet-translator and comparing him to Orpheus, Alcaeus, and Horace. Gobert's assertion of the literary value of translations of poetry echoes Durand's own dedicatory verses, in which he praises Du Bellay's translations as better than his original poetry, despite their apparent disjointedness. Thus, Durand's bilingual Persius is an intervention in literary debate and a promotion of poetic translation, against the view expressed by Du Bellay himself in the Deffence of 1549 .

Despite his rhetorical apology in the preface for its disjointed style, in the translation itself Durand is at pains to make his French Persius harmonize with a contemporary literary aesthetic that valued smoothness, "accord." To do this he must modify and smooth out the Latin Persius. Commenting on and translating the remarks of Cornutus on Persius's style (Satire 5), Durand makes 
the "iunctura [...] acri" (pointed combination) into an "elegant composition" ("compositione carminum eleganti scribis," 58v), and in the translation he writes: "Your language is peaceful, you write in a smooth continuous connected style, so learned and subtle are you" ("Tes propos sont de paix, tu escriptz d'un doux fil, / Et bonne liaison, tant es docte et subtil," 59r). This is not what Persius writes, and it certainly does not characterize his style; Durand has his "verba togae" ("everyday language"), meaning "language of peacetime," 68 and "acer"sharp, pointed, even violent-has been totally eliminated. Again, Durand's attempts to make a new French Persius come up against contradictions, as aesthetic and political demands come into conflict; he had set his text up as a counterpoint to the débat poetry of the Wars (hence "propos de paix"), but his emphasis on smoothness (the "accord" rejected in the preface as inappropriate to the present time of discord) is at odds with the true character of Persius's Latin.

Durand's French Persius is pointedly different from the Latin Persius, and the bilingual presentation of his commentary-translation text points up the contradictions. The text betrays a profound ambivalence towards Persius, whose satire is presented as both inspired poetry and non-poetry, both dangerous and safe, both disjointed and smooth, both pagan and Christian, both Latin and French. Persius is for Durand an author who can serve two quite different readerships simultaneously, and the entire edition partakes of this doubleness and antithesis. The bivalency of the text of Persius is made manifest on the printed page, and Durand's edition stands as an-ultimately failed-attempt to reconcile the contradictions in the text of Persius, and also to reconcile the contradictions inherent in the reading of classical texts in a bilingual culture.

\section{Conclusion}

Translated, mixed-language, and bilingual commentary editions of the classics produced during the French Renaissance moved between different spheres and answered the needs of various audiences: from noble dedicatees, to elementary and more advanced students in the humanist schoolroom, to participants in vernacular literary culture. Although the translated commentary editions of the early sixteenth century were primarily produced for aristocratic book 
buyers not necessarily interested in humanistic study, they could also be put to use as study editions and could reach a new class of bourgeois readersthough not without accompanying anxieties. They might also be used as language-learning aids for both Latin and French. From the second third of the century, bilingual school editions began to be produced originating from and intended for use in the humanist colleges. The presence of the vernacular in these editions reflected current-though often disavowed-teaching practices. The vernacular was employed primarily as a means to access the Latin, but the two languages might also be presented in a comparative way. As the century progressed, the vernacular came to be accepted more widely in the grammar class and beyond as a language of instruction and ultimately a subject of study. Many of the producers of such editions were Protestants (R. Estienne, Cordier, Davantès); but innovations in bilingual editions were not the preserve of Protestant pedagogy, and Catholics like Durand might also put them to political uses. Bilingual commentary editions not only are relevant to early education but also chart developments in literary translation and in vernacular poetics. In the last third of the century, editors and translators of bilingual editions began to privilege French, emphasizing the literary qualities of their translations and responding to theories of poetic translation and to trends in vernacular poetry; and they were attentive to the different needs and interests of the different language communities, favouring mixed-language presentations that highlighted difference over bilingual parallelism. The tendency of bilingual presentations to elide differences between languages, to subordinate French to Latin, or to fit them into comparative schemes, gives way to a greater awareness of how such presentations might expose and exploit the dynamic interactions of Latin and the vernacular. 